\title{
Editorial
}

\section{Pharmacognosy Communications: The Scope of Pharmacognosy}

\author{
I. E. Cock ${ }^{a, b *}$
}

${ }^{a}$ Biomolecular and Physical Sciences, Nathan Campus, Griffith University, 170 Kessels Rd, Nathan, Brisbane, Queensland 4111, Australia. ${ }^{b}$ Environmental Futures Centre, Nathan Campus, Griffith University, 170 Kessels Rd, Nathan, Brisbane, Queensland 4111, Australia

Pharmacognosy is the branch of pharmacology that studies drugs in their crude and/or natural states. ${ }^{[1]}$ In general, when we describe pharmacognosy, we are usually referring to plant based medicinal systems. However, it is important to note that medicinal preparations may also be derived from animal sources as well as from fungi and microorganisms. Indeed, the discovery of the fungal antibiotic agent penicillin (from Penicillinum spp. . $^{[2]}$ is one of the most important medicinal findings to date. Many other useful medicinal products are also derived from fungi including the immunosuppressant mycophenolic acid (also from Penicillinum spp. . $^{[3]}$ and purgative anthraquinone emodin (from Penicillium islandicum). ${ }^{[4]}$ Also, numerous hallucinogenic substances (eg. psilocin and psilocybin) are produced by Psilocybe spp. (family Tricholometaceae) of fungi. ${ }^{[5]}$

Similarly, numerous medicinal agents are produced by bacteria, especially further antibiotic agents. Very early studies demonstrated the antibiotic potential of bacteria towards other bacterial species. In 1887 it was accidently discovered that prior injection of Streptococcus erysipelatis protected guinea pigs from developing cholera when injected with Vibrio cholera. ${ }^{[6]}$ Furthermore, it was also shown that previous injection of either Streptococcus erysipelatis or Pseudomonas aeruginosa also prevented the development of anthrax in experimental animals injected with Bacillus anthracis ${ }^{\left[{ }^{6}\right]}$ and that pre-injection of sterilised cultures of the protective bacteria have the same protective effect as live bacteria. ${ }^{[7]}$ This discovery stimulated further studies into the antibiotic activity of bacteria, resulting in the discovery of streptomycin, chloramphenicol, chlortetracycline, tetracycline, erythromycin, neomycin and numerous other antibiotics, especially from Streptomyces spp. (family Streptomycetaceae). Other bacteria, particularly Bacillus spp., are noted for their production of antibiotic polypeptides such as actinomycin, ${ }^{[8]}$ bacitracin, ${ }^{[9]}$ tyrothrycin $^{[10]}$ and polymixin. ${ }^{[10]}$ These antibiotic polypeptides were initially not widely used as they also display strong cytotoxic

${ }^{*}$ Correspondence: Tel.: +61 7 37357637; fax: +61 737355282

E-mail: I.Cock@griffith.edu.au (I. E. Cock).

DOI: $10.5530 /$ pc.2011.1.1 properties. More recently, there is renewed interest in their use due to their antitumor potential. Indeed, the bacterial antibiotic polypeptides doxorubicin, daunorubicin and actinomycin $\mathrm{D}$ are now routinely used in the treatment of a variety of cancers. ${ }^{[1,12]}$

Although the number of animal derived pharmacognostical agents is small when compared to fungi, bacteria and plants, there has recently been an increase in interest in marine creatures as a source of new drugs. Marine invertebrates in particular, account for much of the recent publications describing animal pharmacognosy. Some species of sponges have been found to have antibacterial, antifungal, antimalarial, cytotoxic and anticancer bioactivities. ${ }^{[13]}$ Furthermore, sponges produce interesting metabolites including bromophenols, cyclic peroxides, peroxyketals and modified sesquiterpenes which warrant further investigation. ${ }^{[13]}$ The soft coral Sarcophyton glaucum produces the diterpenoids sarcophytol A and sarcophytol A, which have tumour inhibiting bioactivity. ${ }^{[14]}$

Whilst marine animals are receiving much recent interest, there are also many examples of pharmacognostical agents derived from terrestrial animals. For examples, bees (Apis mellifica) provide us with multiple useful medicinal properties. The antimicrobial activity of honey produced by bees feeding on some plant species is known to be exceptionally good. Manuka honey (made by bees feeding on the Eastern Australian/New Zealand plant Leptospermum scoparium) is an especially good antimicrobial agent. ${ }^{[15]}$ Additionally, beeswax and royal jelly are also reported to have therapeutic properties. ${ }^{[16]}$ Toad skins contain cardioactive agents and were used to treat oedema prior to the development of more effective agents. ${ }^{[17]}$ Pharmacognostic agents produced by vertebrates include lanolin from wool, gelatine and musk. In my own region of the world (Australia) there is also much interest in oils obtained from emu for its many therapeutic properties. ${ }^{[18]}$

Inorganic chemicals may also have important medicinal properties. Silver is particularly well known for its antibacterial activity ${ }^{[19]}$ and has been used since the times of ancient Greece. Silver nanoparticles have also been shown to have a potent cytoprotective bioactivity towards HIV infected cells. ${ }^{[20]}$ Gold thiolates have been 
used in the treatment of rheumatoid arthritis and as anti-tumour agents (as reviewed in Parish and Cottrill). ${ }^{[21]} \mathrm{A}$ variety of copper and iron complexes demonstrate potent cytotoxic activities against human cancer cells. ${ }^{[22]}$ Recent studies have highlighted the importance of selenium in blocking the production of reactive oxygen species (ROS) and thus blocking oxidative stress and its associated disease states and medical conditions. ${ }^{[23]} \mathrm{A}$ variety of other inorganic molecules and ions also have medicinal promise, possibly also through their maintenance of cellular redox state.

Despite the importance of pharmacognostic agents from fungi, microorganisms and animals, plants provide us with the greatest variety of medicinal agents and arguably hold the most promise for future drug discovery. Asian medicinal botany in particular has been especially well documented. Traditional Chinese Medicinal (TCM) systems and Indian Ayuverda are widely practiced with approximately $85 \%$ of Indians regularly using crude plant formulations for the treatment of various diseases and ailments. ${ }^{[24]}$ Similarly, African and Middle Eastern medicinal ethnobotanies are also widely practiced well documented. Even allopathic/Western medicine practiced in developed countries owes much to our understanding of plant based remedies. Indeed, it has been estimated that approximately $25 \%$ of all prescription drugs currently in use are originally derived from plants. ${ }^{[6,27]}$ Furthermore, approximately $75 \%$ of new anticancer drugs marketed between 1981 and 2006 are derived from plant compounds. ${ }^{[2]}$ Recently, there has been an increase in interest in pharmacognosy and natural therapies due to the perception that natural therapeutics offer a safer alternative than synthetic formulations due to their organic origin. This is reflected in the dramatic increase in publications in pharmacognosy journals over the period 2005-2010. ${ }^{[28]}$ It is evident that a further publication outlet is required to accommodate this expanding field.

Pharmacognosy Communications is a new journal published by Pharmacognosy Network Worldwide [www.phcog.net]. We aim to publish high quality original research articles, methods, techniques and evaluation reports, critical reviews, short communications, commentaries and editorials of all aspects of pharmacognosy research. The journal is aimed at a broad readership, publishing articles on all aspects of pharmacognosy, and related fields. The journal aims to increase understanding of pharmacognosy as well as to direct and foster further research through the dissemination of scientific information by the publication of manuscripts. The submission of original contributions in all areas of pharmacognosy are welcomed.

The journal aims to cater the latest outstanding developments in the field of pharmacognosy and natural products and drug design covering but not limited to the following topics:

- Pharmacognosy and pharmacognistic investigations

- Research based ethnopharmacological evaluations

- Biological evaluation of crude extracts, essential oils and pure isolates
- Natural product discovery and evaluation

- Mechanistic studies

- Method and technique development and evaluation

- Isolation, identification and structural elucidation of natural products

- Synthesis and transformation studies

We look forward to receiving your valuable pharmacognosy communications.

\section{REFERENCES}

1. The American Heritage Medical Dictionary, 2007, Houghton Mifflin Company, USA

2. Fleming $A, 1928$, On the antibacterial action of cultures of a Penicillium with special reference to their use in the isolation of B. Influenza. British Journal of Experimental Pathology, 10, 216-226.

3. Florey HW, Gilliver K, Jennings MA, Sanders AG, 1946, Mycophenolic acid, an antibiotic from Penicillium brevi-campactum Dierckx. Lancet, 1, 46-49.

4. Ghosh AC, Manmade A, Demain AL, 1977, Toxins from Penicillium islandicum Sopp. In Mycotoxins in Human and Animal Health, Edited by Rodricks JV, Hesseltine CW, MehIman MA, Pathotox, Chicago, USA, 625-638.

5. Hofmann A, Heim R, Brack A, Kobel H, 1958, Psilocybin ein psychotroper Wirkstoff aus dem moscikanischen Rauschpilz Psilocybe mexicana Heim. Experientia, 14, 107.

6. Bouchard C, 1889 , Influence qu'exerce sur la maladie charbonneuse l'inoculation du bacilli pyocyanique, Comptes Rendus de l'Académie des Sciences, 108, 713-714.

7. Woodhead GS, Wood C, 1889 , De l'action antidotique exercée par les liquids pyocyaniques sur le cours de la maladie charbonneuse. Comptes Rendus de l'Académie des Sciences, 109, 985-988.

8. Waksman SA, Woodruff HB, 1940, Bacteriostatic and bactericidal substances produced by soil actinomycetes. Proceedings of the Society for Experimental Biology and Medicine, 45, 609-614.

9. Johnson BA, Anker H, Meleney FL, 1945, Bacitracin: a new antibiotic produced by a member of the B. Subtilise group. Science, 102, 376-377.

10. Dubos RJ, Hotchkiss RD, 1941, The production of bactericidal substances by aerobic sporulating Bacilli. Journal of Experimental Medicine, 73, 5, 629-640.

11. Lasek W, Giermasz A, Kuc K, Wańkowicz A, Feleszko W, Golab J, Zagozdzon R, Stoklosa T, Jakobisiak M, 1996, Potential of the anti-tumor effect of actinomycin $\mathrm{D}$ by tumor necrosis factor $\alpha$ in mice: Correlation between in vitro and in vivo results. International Journal of Cancer, 66, 374-379.

12. Weiss RB, 1992, The anthracyclines: will we ever find a better doxorubicin? Seminars in Oncology, 19, 6, 670-686.

13. Fusetani N, Matsunaga S, 1993, Bioactive sponge peptides. Chemistry Reviews, 93, 1793-1806

14. Wei H, Frenkel K, 1992, Suppression of tumor promoter-induced oxidative events and DNA damage in vivo by sarcophytol A: A possible mechanism of antipromotion. Cancer Research, 52, 2298-2303.

15. Brophy JJ, Goldsack RJ, Bean AR, Forster PI, Lepschi BJ, 1991, Leaf essential oils of the genus Leptospermun (Mytaceae) in Eastern Australia. Part 5, Leptospermum continentale and its allies. Flavour and Fragrance Journal, 14, 98-104.

16. Fujii A, 1995, Pharmacological effect of royal jelly. Honeybee Science, 16, 97-104

17. Chen KK, Kovariková A, 1967, Pharmacology and toxicology of toad venom. Journal of Pharmaceutical Sciences, 56, 12, 1535-1541.

18. Whitehouse MW, Turner Ag, Davis CKC, Roberts MS, 1998, Emu oil(s): A source of non-toxic transdermal anti-inflammatory agents in Aboriginal medicine, Inflammopharmacology, 6, 1-8.

19. Feng QL, Wu J, Chen GQ, Cui FZ, Kim TN, Kim JO, 2000, A mechanistic study of the antibacterial effect of silver ions on Escherichia coli and Staphylococcus aureus, Journal of Biomedical Materials Research, 52, 662-668.

20. Sun RWY, Chen R, Chung NPY, Ho CM, Lin CLS, Che CM, 2005, Silver nanoparticles fabricated in Hepes buffer exhibit cytoprotective activities towards HIV-1 infected cells. Chemistry Communications, 40, 5059-5061.

21. Parish RV, Cottrill SM, 1987, Medicinal gold compounds, Gold Bulletin, 20, 3-12.

22. Easmon J, Pürstinger $G$, Heinisch G, Roth T, Fiebig HH, Holzer W, Jäger W, Jenny M, Hofmann J, 2001, Synthesis, cytotoxicity, and antitumor activity of copper(II) 
and iron(II) complexes of ${ }^{4} \mathrm{~N}$-azabiclo[3.2.2]nonane thiosemicarbazones derived from acyl diazines, Journal of Medicinal Chemistry, 44, 13, 2164-2171.

23. Venardos K, Harrison G, Headrick J, Perkins A, 2004, Effects of dietary selenium on glutathione peroxidise and thioredoxin reductase activity and recovery from cardiac ischemia-reperfusion, Journal of Trace Elements in Medicine and Biology, 18, 1, 81-88.

24. Kamboj VP, 2000, Herbal medicine. Current Science, 78, 35-39.
25. Newman DJ, Cragg GM, Snader KM, 2000, The influence of natural products on drug discovery. Natural Product Reports, 17, 215-234.

26. Hostettmann K, Hamburger M, 1993, Search for new lead compounds of natural origin. In Perspectives in Medical Chemistry, Testa B, Kyburz E, Fuhrer W, Giger R (eds), Verlag Helvitica Acta, Basel.

27. Ahmed MKK, 2011, New challenges in the new year for Pharmacog Mag.: 5 years of quality publication. Pharmacognosy Magazine, 7, 25, 1-3.

\section{ABOUT JOURNAL}
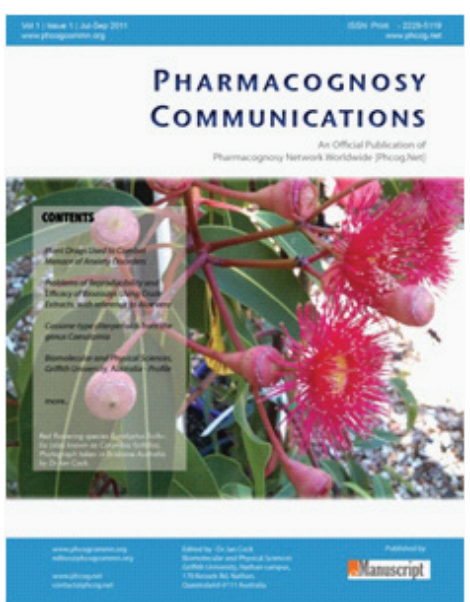
aimed at a broad readership, publishing articles on all aspects of
pharmacognosy, and related fields. The journal aims to increase
understanding of pharmacognosy as well as to direct and foster aimed at a broad readership, publishing articles on all aspects of
pharmacognosy, and related fields. The journal aims to increase
understanding of pharmacognosy as well as to direct and foster

P h a r m a c o g n o s y Communications [Phcog Commn.] www.phcogcommn. org is a new journal published by Pharmacognosy Network Worldwide [www.phcog.net]. It is a peer reviewed journal aiming to publish high quality original research articles, methods, techniques and evaluation reports, critical reviews, short communications, commentaries and editorials of all aspects of medicinal plant research. The journal is further research through the dissemination of scientific information by the publication of manuscripts. The submission of original contributions in all areas of pharmacognosy are welcome.

The journal aims to cater the latest outstanding developments in the field of pharmacognosy and natural products and drug design covering but not limited to the following topics:

- Pharmacognosy and pharmacognistic investigations

- Research based ethnopharmacological evaluations

- Biological evaluation of crude extracts, essential oils and pure isolates

- Natural product discovery and evaluation

- Mechanistic studies

- Method and technique development and evaluation

- Isolation, identification and structural elucidation of natural products

- Synthesis and transformation studies 